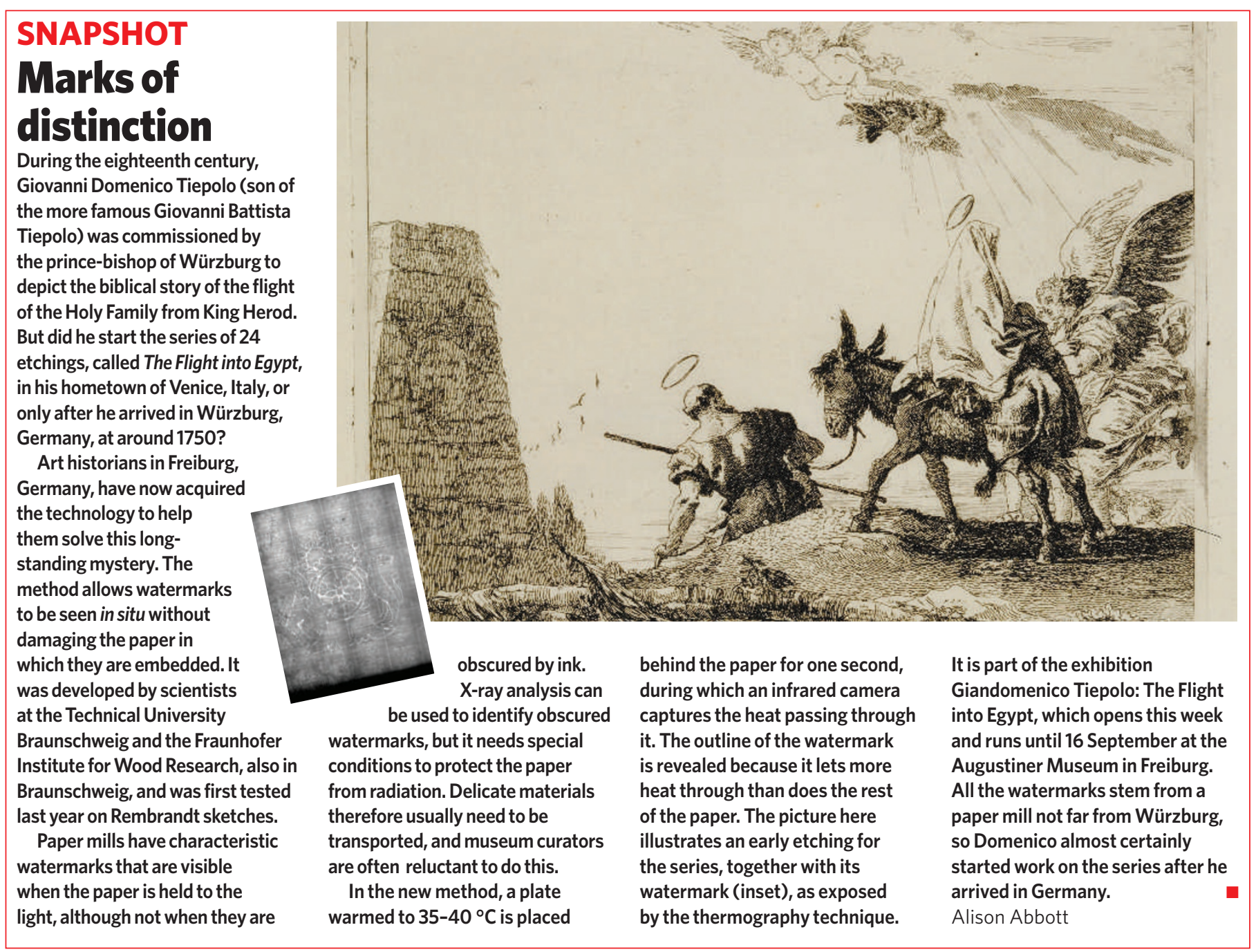

\title{
French universities to gain control
}

"In the race against Stanford, Cambridge or Harvard, French universities run with their laces tied together and a backpack full of stones." So said Nicolas Sarkozy in the run-up to the French presidential election, as he pledged to reform the country's archaic university system. As the new president, Sarkozy has now personally weighed in on a reform bill that will be fasttracked through parliament this summer.

The bill, adopted by the cabinet on 4 July, is historic as it would make France's 85 public universities much more independent, largely freeing them from the current centralized state control.

Sarkozy has also confirmed that universities will receive an extra $€ 5$ billion (US $\$ 6.8$ billion) over the next five years. Most people agree that this sum, and much more, is badly needed. Whereas the élite Grandes Ecoles — which scoop the best few per cent of students - are well-heeled, the underfunded universities must cope with most of the remainder.

The bill would allow universities to own and manage their own buildings, to control their budgets, and to hire and set salaries as they see fit, all of which are currently controlled by the science and higher-education ministry. At present, a star biologist might earn no more than a philosopher of the same bureaucratic grade. Top international research talent often passes French universities by.

The bill would also modernize governance. University presidents have had few real powers, and whereas Anglo-Saxon universities typically form committees to headhunt the best leader, in France the presidents are elected by
130 members of the various university panels, and can serve only one four-year term. The university's direction is decided largely by a 60 -strong board of directors that is often highly politicised.

Under the new law, the board would be "French universities run with their laces tied together and a backpack full of stones." streamlined to 20-30 people, with an absolute majority agreeing on a president. The president, elected for a maximum of two four-year terms, would have executive power over almost all university affairs.

The bill is just the start of broader university reform, says prime minister François Fillon, who has described the future of French universities as the most important item on his domestic agenda.

Declan Butler 